Ляпустин Павел Константинович, к.т.н., доцент, Ангарский государственный технический университет, e-mail: Ipk62@mail.ru

Кобак Алексей Александрович, обучающийся, Ангарский государственный технический университет, e-mail: alexeikobak@yandex.ru

ОЦЕНКА СОЦИАЛЬНО-ЭКОНОМИЧЕСКОГО УЩЕРБА ОТ ДОРОЖНОТРАНСПОРТНЫХ ПРОИСШЕСТВИЙ

\title{
ASSESSMENT OF SOCIO-ECONOMIC DAMAGE FROM ROAD ACCIDENTS
}

\begin{abstract}
Аннотация. Рассмотрена проблема оценки дорожно-транспортных происшествий. Предложен вариант нового метода оценки ущерба от дорожно-транспортных происшествий.

Ключевые слова: оценка, метод, дорожно-транспортное происшествие.

Abstract. The problem of assessing traffic accidents is considered. A variant of a new method for assessing damage from traffic accidents is proposed.
\end{abstract}

Keywords: assessment, method, traffic accident.

В настоящее время с каждым годом начинают происходить всё больше и больше дорожно-транспортных происшествий. По Ангарску за январь 2020 г. таких происшествий составляет около 86, по Иркутской области составляет 230, по всей России составляет примерно 11000 аварий, что на 7 процентов больше прошлогоднего показателя. Каждый день по России случаются 460 дорожно-транспортных происшествий [1].

Согласно нормативно-правовому документу Р-03112199-0502-00 «Методика оценки и расчета нормативов социально-экономического ущерба от дорожно-транспортных происшествий» существует несколько методов оценки социально-экономического ущерба от дорожно-транспортных происшествий [2]. Применяемые методы зависят от разных фракторов, в частности, от вида ущерба:

1. Ущерб в результате гибели и ранения людей;

2. Ущерб в результате повреждения транспортных средств;

3. Ущерб в результате порчи груза;

4. Ущерб в результате повреждения дороги.

Процедура оценки дорожно-транспортных происшествий занимает очень длительное время, необходимо собрать достаточно большой перечень документов и дождаться окончательного результата экспертизы, на это могут уходить как недели, так и месяцы.

В процессе рассмотрения данной проблемы был выявлен новый метод, метод визуальной экспертизной оценки. Метод состоит в следующем: создаётся программа на федеральном уровне, при происшествии участник включает программу на телефоне и начинает описывать всю ситуацию, с 
приложением фотографий и выбором предлагаемых пунктов, то есть создаётся заявление, которое направляется в базу данных экспертов. Эксперты принимают заявление и начинают оценивать ущерб и проводить анализ происшествия. В это время эксперты направляют на место происшествия комиссара, и ко времени прибытия комиссара у него уже будет примерный взгляд на то, что произошло. Так же это заявление после проверки экспертами будет направляться в страховую компанию и другие инстанции, что подготовит их к обращению участника происшествия.

Данный метод значительно уменьшит время, затрачиваемое на подготовку документов, на различные справки и прочий перечень документов, необходимый для оценки ущерба. К преимуществам данного метода можно отнести:

- снижение времени и затрат на оценку ущерба;

- внедрение искусственного интеллекта в программу - компьютер сам будет рассчитывать ущерб, причинённый в результате дорожнотранспортного происшествия;

- $\quad$ за короткий срок участник будет знать о штрафах, ущербах, компенсации и страховых выплатах;

- можно рассчитать не только ущерб от повреждения транспортных средств, но и ущерб от порчи груза и ущерб от повреждения дороги.

Из недостатков можно выделить следующее:

- невозможность рассчитать ущерб по программе без подключения к интернету;

- невозможно рассчитать ущерб в результате гибели или ранения людей;

- нельзя рассчитать косвенные затраты, то есть затраты на потери народного хозяйства вследствие временного или полного выбытия человека из сферы материального производства, нарушения производственных связей и моральные потери.

Предлагаемый метод оценки ущерба от дорожно-транспортных происшествий позволит сделать приблизительный анализ, и определить, покроет ли страховка или компенсация тот ущерб, который возник в результате дорожно-транспортного происшествия.

\section{ЛИТЕРАТУРА}

1. Показатели состояния безопасности дорожного движения / Картограмма дорожно-транспортных происшествий за январь 2020 [Электронный ресурc]. - URL: http://stat.gibdd.ru/ (дата обращения 17.03.2020).

2. Р-03112199-0502-00 Методика оценки и расчета нормативов социально-экономического ущерба от дорожно-транспортных происшествий. 